\title{
Recruitment studies of the mussel Mytilus trossulus on artificial substrate near high energy shores of the north-eastern Baltic Sea
}

\author{
Ingrida Purina, leva Barda* \\ Latvian Institute of Aquatic Ecology, Voleru 4, Rīga LV-1007, Latvia \\ ^Corresponding author, E-mail: ieva.barda@lhei.lv
}

\begin{abstract}
Ecological mussel farming in the Baltic Sea has gained attention due to ability of mussels to bind high concentrations of nitrogen and phosphorus in their tissues. Removal of mussels could serve as abatement of eutrophication. The Latvian coast of the Baltic Sea is one of the most exposed coastlines of the Baltic due to the highest wind and wave energy. Experimental units for mussel recruitment were placed in three locations at 15,20 and $25 \mathrm{~m}$ depth assess the potential for mussel farming. The spawning maximum was observed in the middle of May, followed by recruitment in June. Recruitment of Mytilus was observed on all experimental units with higher densities at 6 to $10 \mathrm{~m}$ depth. Observations suggest that mussels can use artificial substrate for recruitment even near high energy shores. However, if mussel farming is to take place, submerged offshore farming techniques should be considered.
\end{abstract}

Key words: artificial substrate, Baltic Sea, Mytilus, recruitment. Abbreviations: Chl $a$, chlorophyll a; PSU, practical salinity units.

\section{Introduction}

Mussel cultivation in the Baltic Sea has never received any commercial interest, as Baltic mussels are growing at the lowest limits of salinity range (4 to 7 practical salinity units; PSU) and since mussels reach only 3 to $4 \mathrm{~cm}$ size (Kautsky 1982a), too small for human consumption. However, recently mussel cultivation in the Baltic Sea has gained attention from the ecological viewpoint. It is well known that mussels (Mytilus) play an important role in the ecosystem of coastal waters and estuaries (Dankers, Zuidema 1995) creating specific mussel-bed faunal assemblages (Dittmann 1990; Saier 2002), promoting sedimentation (Verwey 1952) and regulating the concentrations of nutrients and phytoplankton (Dame, Dankers 1988; Asmus, Asmus 1991). As sessile filter-feeders molluscs are placed on the lowest levels of aquatic food chains. Molluscs filter phytoplankton, detritus, bacteria from the surrounding water, thus accumulating large quantities of nitrogen and phosphorus in their tissues. It is estimated that mussels contain $1 \%$ nitrogen and $0.2 \%$ phosphorus as wet weight (Lindahl et al. 2005). Cultivating and harvesting mussels (Mytilus edulis/trossulus) may be a sustainable method for making products of high nutritional value while simultaneously recycling nutrients from the sea to the land (Lindahl et al. 2005).

The Latvian coast of the Baltic Proper can be characterized as one of the most open and exposed shores in the Baltic Sea. In these high energy shores distribution of Mytilus strongly depends on presence of hard bottom substrata, pebbles and boulders. Hard bottoms can be found from 7 to $10 \mathrm{~m}$ till 40 to $60 \mathrm{~m}$ depth along the Latvian coastline of the Baltic Proper (Krūmiņš, Ozoliṇa 1998). In these areas benthic communities with Mytilus can be observed from $7 \mathrm{~m}$ up to $54-60 \mathrm{~m}$ depth with abundant biomass of Mytilus trossulus reaching on average $1.14 \mathrm{~kg}$ $\mathrm{m}^{-2}$ (Kostrichkina, Kaleja 1980; Olenin 1997). However previous experience showed that on the Latvian open coast, mussels grow specifically on large boulders $(>40 \mathrm{~cm}$ ), implying the necessity of substrate stability.

In this study we explored the potential recruitment of Mytilus on ropes and determined depth preferences in a gradient of hydrodynamic forces, as well as identified environmental factors promoting growth of mussels. The obtained knowledge is necessary for the future development of mussel farms on the Latvian shores of the Baltic Sea.

\section{Materials and methods}

\section{Site description}

The Latvian coastline of the Baltic Proper forms almost straight line without islands or coastal inlets, where wind and waves are the major hydrodynamic forces influencing the coastal habitats. The highest hydrodynamic force falls in the area between latitudes $57^{\circ} 00^{\prime}$ and $57^{\circ} 30^{\prime}$ where the wave closure depth reaches $6.58 \mathrm{~m}$. To the south of this area 
the closure depth decreases and reaches a local minimum $(4.35 \mathrm{~m})$ near the border between Latvia and Lithuania (Soomere et al. 2011). Measured orbital wave velocity at bottom squared has highest impact at 2 to $5 \mathrm{~m}$ depth, but decreases by $50 \%$ at $10 \mathrm{~m}$ depth and diminishes further with depth (Müller-Karulis et al. 2007). Dominant coastal northward current and wave action ensure sand flow along the coastline till the $5 \mathrm{~m}$ depth covering the underlying hard substrates.

Three different study sites were chosen in the southern part of Latvian coastal zone to study Mytilus recruitments. The sites differed in effect of hydrodynamic forces: Pavilosta as an exposed site with the strongest influence of waves, Liepaja as less influenced and Jurmalciems with the least impact. The study site Jurmalciems was located in the neutral zone of the marine protected area Nida-Perkone, where $80 \%$ of the territory was covered by reefs with dense Mytilus trossulus, and Furcellaria lumbricalis stands.

\section{Experimental design}

Pilot studies were started in May 2013 when the experimental units for study of mussel recruitment and growth were installed in Jurmalciems (JM), Liepaja (LI) and Pavilosta (PV) in a depth gradient at 15, 20 and $25 \mathrm{~m}$ depths (Fig. 1). The horizontal ropes for the recruitment of mollusks were installed at 2, 4, 6, 10 and $14 \mathrm{~m}$ depth to determine the potential recruitment intensity gradient (Fig. 2). Previously used polypropylene ropes were used for experimental units in order to increase the surface area for mussels. In September 2013 part of the horizontal ropes were removed by scuba divers for assessment of mussel recruitment.

\section{Sampling}

The experimental units were surveyed monthly from May to September, 2013. Samples for the physical and biological parameters were taken simultaneously. Water temperature, salinity, and oxygen concentration were measured at each station at 2 and $14 \mathrm{~m}$ depth using a water probe (SBE 19plus SeaCAT, USA).

Water samples for chlorophyll $a(\mathrm{Chl} a)$ analysis were sampled at 2 and $14 \mathrm{~m}$ depth with a water sampler. Concentration of Chl $a$ was measured according to standard method of the Manual for Marine Monitoring in the COMBINE Programme of HELCOM (HELCOM 2006) and further analyzed by spectrophotometer (Cary 100 Conc UV-Visible Spectrophotometer).

\section{Sampling of mussel larvae}

Seawater samples for larval stages of mussels were collected at $20 \mathrm{~m}$ stations in PV-20, LI-20 and JM-20 using zooplankton net (100 $\mu \mathrm{m}$ mesh size) from 0 to $19 \mathrm{~m}$ depth. Samples were preserved with formalin solution till a final concentration of $4 \%$. Putative Mytilus trossulus larvae were counted with a stereo microscope (Leica) and four size groups were estimated. Only larvae from $140 \mu \mathrm{m}$ to $300 \mu \mathrm{m}$

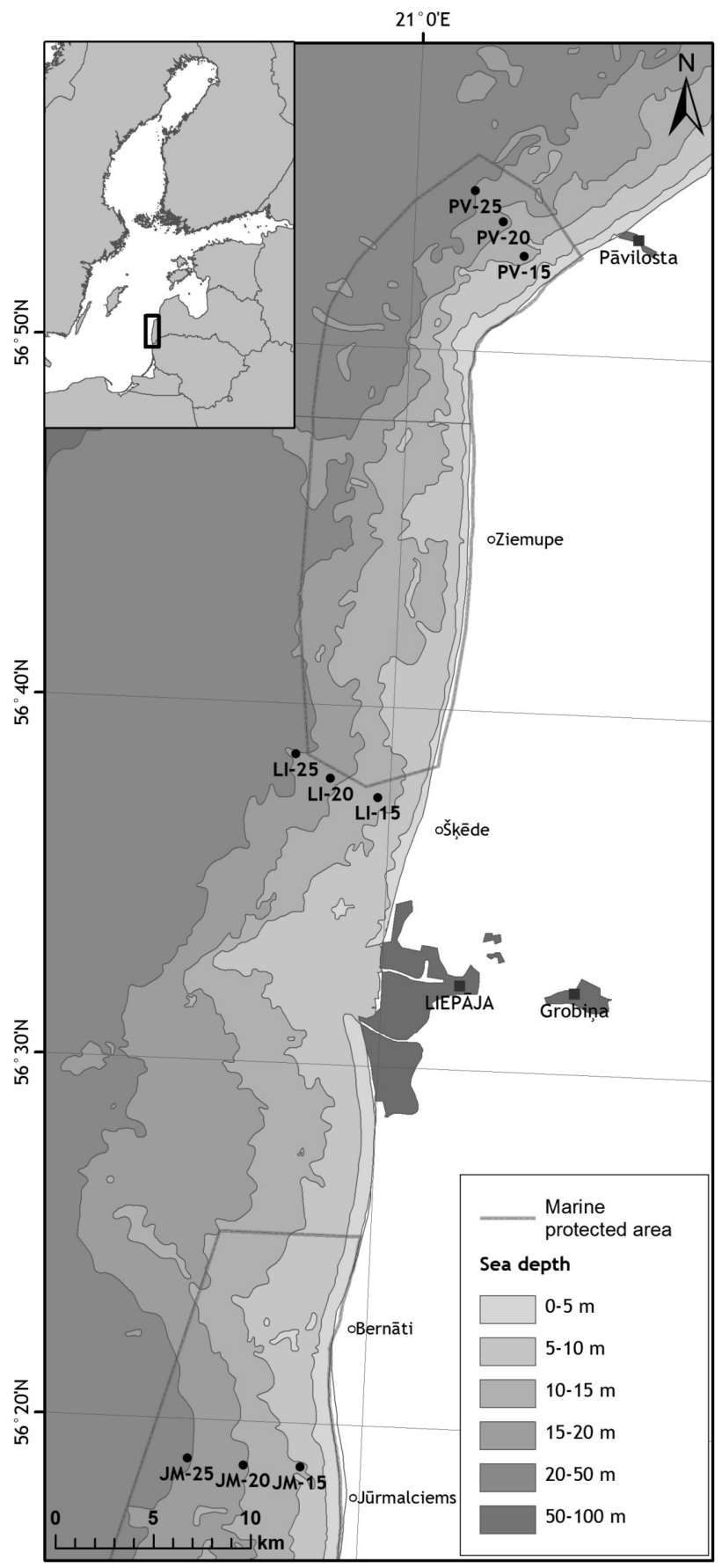

Fig. 1. Map of study sites: Jurmalciems (JM-15; JM-20; JM-25), Liepaja (LI-15; LI-20; LI-25) and Pavilosta (PV-15; PV-20; PV-25). $(-15 ;-20 ;-25$ representing the depth $(\mathrm{m})$ of station).

were counted in the samples as it is considered that larval metamorphosis occurs at size 210 to $300 \mu \mathrm{m}$ (Gosling 2003). Occasionally, molluscs of size 300 to $1000 \mu \mathrm{m}$ were encountered in the samples but were omitted from the final counts. All larvae were counted as Bivalvia larvae, assuming that $M$. trossulus was the dominating Bivalvia species in the area (Lagzdinsh et al. 1987). Additionally, larvae of Dreissena polymorpha, Mya arenaria, and Macoma balthica could be encountered in the samples. 


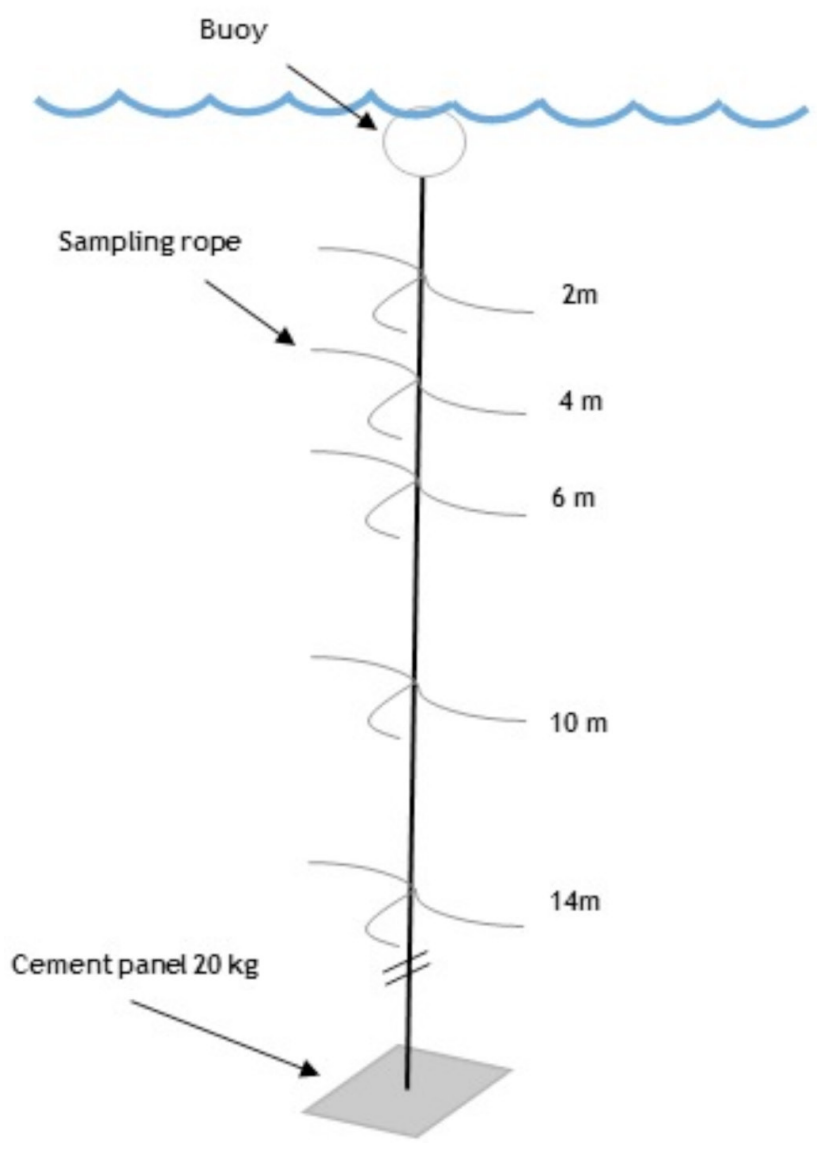

Fig. 2. Experimental units for mussel recruitment studies.

\section{Mussel counting}

In September, one of the three horizontal ropes of each experimental unit was cut off at each depth and each sampling site. In total 40 ropes were collected. One sampling site (LI-20) had been destroyed, while horizontal ropes $(6 \mathrm{~m})$ at JM-15 and (2 and $14 \mathrm{~m})$ at PV-25 were missing. Ropes with mussels were placed in plastic bags and frozen till analysis. In the laboratory the ropes were thawed and carefully washed clean with water spurt over $1,0.5$ and $0.125 \mathrm{~mm}$ sieves to collect the settled animals, as well as to achieve initial size fractionation. Settled animals were collected from the sieves, blotted on paper and weighed. All Mytilus individuals were collected for microscopical counts. The length of randomly chosen 55 individuals was measured under stereo microscopes (Leica) in each sample and divided into size classes. After counting the mussels were blotted on the paper and weighed for the raw estimation of the wet weight $\left(\mathrm{mg} \mathrm{cm}^{-2}\right)$.

\section{Statistical analysis}

The data were first tested for normality using a ShapiroWilk test. We used a non-parametric Kruskall-Wallis one-way ANOVA test to compare mussel size, abundance, biomass among sampling sites, as well as among horizontal ropes between stations. Whenever a significant $(p<0.05)$ effect was established on a parameter response, a post-hoc Bonferroni test for multiple comparison between paired means was applied to detect significant differences $(p<$ 0.05). Spearman rank correlation coefficient $(p<0.05)$ among mussel size, biomass, abundance and physiochemical variables were determined for each station. All statistical analyses were performed using R-2.14.0 software package.

\section{Results}

\section{Physiochemical variables}

The ranges of physiochemical variables are summarized in Table 1.

In the selected study sites the salinity ranged from 5.81 to $7.73 \mathrm{PSU}$. The lowest salinity was observed in May in the JM-15, JM-20 and LI-15 sites (2 to $4 \mathrm{~m}$ depth). In the remaining study period salinity fluctuated from 6.5 to 7.7 PSU in all stations with minor differences between upper and lower layers.

Temperature varied from $3.66-7.70{ }^{\circ} \mathrm{C}$ in May to maximum $18.48-19.56{ }^{\circ} \mathrm{C}$ in August, with the expressed differences between surface water temperature at $2 \mathrm{~m}$ and at $14 \mathrm{~m}$ depth. Sites JM-15, JM-20 and LI-15 showed marked thermal stratification in May and June, reaching a temperature gradient of almost $10^{\circ} \mathrm{C}$ between $2 \mathrm{~m}$ and 14 $m$ depth (Table 1). A less expressed temperature difference between water layers was observed in PV sites ( 0 to 4 $\left.{ }^{\circ} \mathrm{C}\right)$. In contrast, in July-September the water column was completely mixed in all sampling sites.

Oxygen concentrations were rather high throughout the season reaching from 5.80 to $9.71 \mathrm{ml} \mathrm{L}^{-1}$ in all sites

Table 1. Ranges of physiochemical (temperature, salinity, dissolved oxygen) and biological parameter (Chl $a$ ) in the study sites from May till September, 2013

\begin{tabular}{|c|c|c|c|c|c|}
\hline Station & Depth (m) & Temperature $\left({ }^{\circ} \mathrm{C}\right)$ & Salinity (PSU) & $\begin{array}{l}\text { Dissolved oxygen } \\
\left(\mathrm{ml} \mathrm{L}^{-1}\right)\end{array}$ & Chl $a\left(\mu \mathrm{g} \mathrm{L}^{-1}\right)$ \\
\hline \multirow[t]{2}{*}{ JM-15; JM-20; JM-25 } & 2 & $4.84-19.56$ & $5.81-7.27$ & $5.86-9.45$ & $1.57-6.67$ \\
\hline & 14 & $3.85-19.53$ & $6.14-7.22$ & $5.80-9.71$ & $0.92-4.93$ \\
\hline \multirow[t]{2}{*}{ LI-15; LI-20; LI-25 } & 2 & $6.80-19.55$ & $6.39-7.73$ & $5.85-9.16$ & $0.76-3.48$ \\
\hline & 14 & $3.66-19.51$ & $6.81-7.59$ & $5.87-9.40$ & $0.89-4.02$ \\
\hline \multirow[t]{2}{*}{ PV-15; PV-20; PV-25 } & 2 & $5.65-18.96$ & $6.60-6.99$ & $5.85-9.11$ & $1.42-4.82$ \\
\hline & 14 & $4.58-18.97$ & $6.73-7.14$ & $5.87-9.20$ & $0.96-3.09$ \\
\hline
\end{tabular}


(Table 1). The highest oxygen concentration was observed in spring due to lower water temperature. The lowest values were detected in August. However, the oxygen saturation was never below $93 \%$ providing conditions favourable for mussel growing.

Chl a concentrations varied from 0.75 to $6.67 \mu \mathrm{g} \mathrm{L}^{-1}$ in the studied period (Table 1). The highest concentration occurred in the JM sites and decreased towards the north, while the lowest values were observed in the PV site. A similar trend of Chl $a$ was observed from coastal sites to open part. Furthermore, also in the upper layer $(2 \mathrm{~m})$, the $\mathrm{Chl} a$ concentration was always higher than at $14 \mathrm{~m}$ depth.

\section{Larval stages of mussels}

Larvae in the small size fraction $(140 \mu \mathrm{m})$ were found in zooplankton samples already at the beginning of May (Fig. 3 ), but the peak was registered in the middle of May. At this time the larvae amount in JM-20 reached up to 11141 individuals $\mathrm{m}^{-3}$. A similar pattern was observed also in sites LI-20 and PV-20, but the number of larvae was significantly lower (5176 and 3255 individuals $\mathrm{m}^{-3}$, respectively). At that time also the highest number of $200 \mu \mathrm{m}$ size larvae was observed (Fig. 3). At the end of June a rapid decline in the numbers of larvae was observed, however small amount of larger larvae in the samples were found till September.

\section{Recruitment of mussels}

Recruitment of mussels was rather scarce (2 to 5 individuals $\mathrm{cm}^{-2}$ ) on the $2 \mathrm{~m}$ deep horizontal ropes in all sites (Fig. 4). Less favorable were also $4 \mathrm{~m}$ ropes, however abundance of mussels increased in sites toward the north and in deeper locations in the sea (15 to 17 individuals $\mathrm{cm}^{-2}$; PV-20, PV-25, LI-25). The best populated were 6 and $10 \mathrm{~m}$ deep horizontal ropes (Bonferroni test $p=0.0051$ and $p=0.0017$, respectively), while the ropes at $14 \mathrm{~m}$ depth were less favorable for recruitment of mussels, with the exception in Jurmalciems sites (JM-20, JM-25).

Similar to trends for abundance, also biomass on $2 \mathrm{~m}$ horizontal ropes was low and did not exceed $6 \mathrm{mg} \mathrm{cm}^{-2}$ in all experimental locations. In all three sites located at Jurmalciems, higher biomass was detected on $10 \mathrm{~m}$ horizontal ropes, reaching $59 \mathrm{mg} \mathrm{cm}^{-2}$ in site JM-15 (Fig. 4). In other locations maximal mussel biomass was established on $6 \mathrm{~m}$ horizontal ropes, with a peak of $88 \mathrm{mg} \mathrm{cm}^{-2}$ in site PV-20. PV-25 was the only site, where biomass was relatively high on 4 and $10 \mathrm{~m}$ ropes.

Size class frequencies were calculated for all sites in three size classes. The best represented was the 1.0 to $1.4 \mathrm{~mm}$ size class, composing more than $40 \%$ of mussels in all sites. Dominance of the smallest size class $(0.24$ to $1.0 \mathrm{~mm}$ ) was observed in sites JM-15, JM-20, JM-25, where mussel size was significantly lower on 2 and $4 \mathrm{~m}$ horizontal ropes than other ropes (Bonferroni test $\mathrm{p}<2 \mathrm{e}$ 16) (Fig. 5). Furthermore, the smallest mussels $(0.87 \mathrm{~mm})$ at Jurmalciems were found in station closer to shore (JM15 ; Bonferroni test $p=0.0184$ ). The biggest mussel size was detected in sites PV-15, PV-20 and PV-25, reaching up to $4.6 \mathrm{~mm}(\mathrm{PV}-20)$. Here, the largest size fraction (1.4 to $>3.0$ $\mathrm{mm}$ ) contained 23 to $40 \%$ from total mussels amount.

\section{Disccussion}

\section{Recruitment and growth of mussels}

Recruitment of mussels was observed on all experimental units at all depths, proving that artificial substrate can be used for mussel growing even near high energy shores.

The upper $4 \mathrm{~m}$ of substrate were not preferred by mussel spat, most probably due to higher influence of wind and wave energy. This tendency was more pronounced in sites located closer to the shore (15 $\mathrm{m}$ depth) where the orbital wave velocity at bottom squared was higher. Kautskty (1982b), in the archipelago of Swedish Baltic coast, found maximal abundance of Mytilus edulis on longterm ropes at 2 to $3 \mathrm{~m}$ depth and the amount gradually decreased to $8-9 \mathrm{~m}$ depth. In our study area the best recruitment was established on 6 to $10 \mathrm{~m}$ horizontal ropes, with lower amounts on $14 \mathrm{~m}$ ropes.

Several of the largest mussels on the ropes reached up

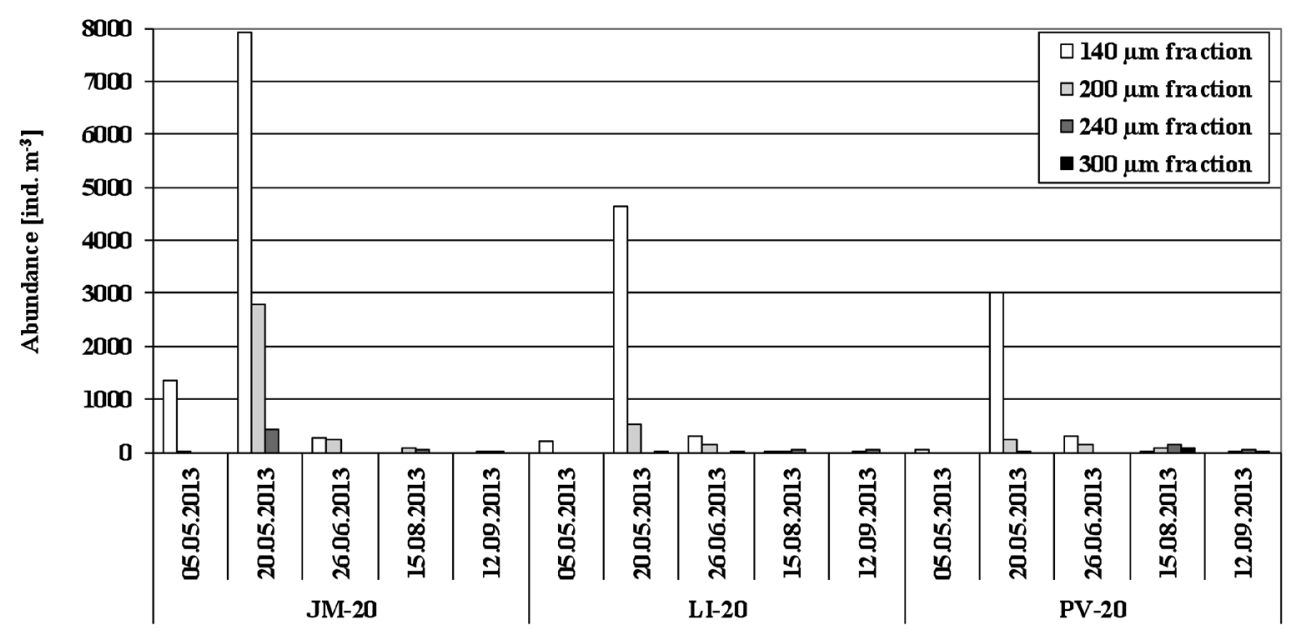

Fig. 3. Abundance of Mytilus pelagic larvae in four size classes in the Jurmalciems (JM-20), Liepaja (LI-20) and Pavilosta (PV-20). 

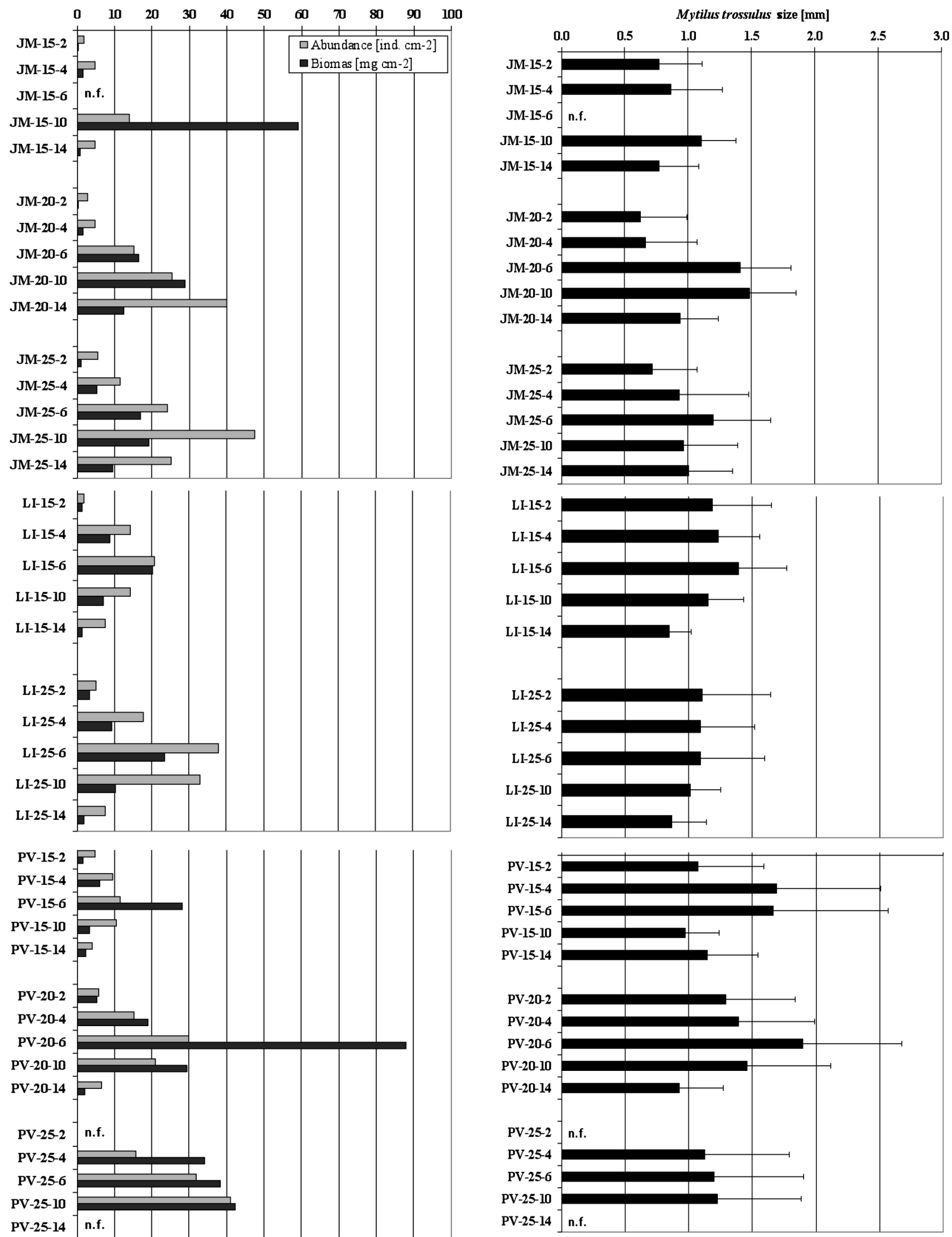

Fig. 4. Abundance and biomass of Mytilus trossulus on the horizontal ropes at 2, 4, 6,10 and $14 \mathrm{~m}$ depth in the study sites. n.f., ropes not found.

Fig. 5. Size of Mytilus trossulus on the horizontal ropes at 2, 4, 6, 10 and $14 \mathrm{~m}$ depth in the study sites. n.f., ropes not found. 
to $4.6 \mathrm{~mm}$ size after five months of growth. Kautsky (1982a) measured the growth rate of juvenile mussels in a caging experiment. The mussels in the northern Baltic (6.8 to 7.0 PSU) had size less than $2 \mathrm{~mm}$ after more than half a year after settlement to length of $3.5 \mathrm{~mm}$ at the end of the first season. This is in agreement with our results, however our study was conducted only for five months and therefore mussel size after full one season could be expected to be even larger.

The best growth rate and largest size attained by mussels was in sites PV-15 and PV-20. Lower growth occurred at sites LI-15, LI-25, JM-25 and JM-20 with the lowest at site JM-15 (Fig. 4). Minimum mussel growth is generally reported from areas with high population density exposed to harsh physical conditions (Seed 1969), but this was not observed in our case. Although abundance of mussels on the horizontal ropes was similar between the sites, the size class distribution was significantly different. Sites PV-15, PV-20 and PV-25 contained 40\% of mussels in the largest size class ( 1.4 to $>3.0 \mathrm{~mm}$ ) compared to 6 to $25 \%$ of that class in JM-15, JM-20, JM-25. We conclude that mussels in the dominant size class 1.0 to $1.4 \mathrm{~mm}$ resulted from the initial settlement of spat released in May. Presence of larger size classes reflected better growth conditions while the smaller size class indicated the opposite - adverse conditions and/or later recruitment.

\section{Number of larvae vs number of recruits}

Based on size difference, comparison of sites showed that the largest (oldest) mussels occurred in Pavilosta and the smallest (youngest) in Jurmalciems (Fig. 5). This contradicts earlier observations of swimming larvae in plankton samples. Zooplankton data suggested that highest recruitment and possibly also highest biomass could be expected in site JM-20 due to significantly larger number of larvae in the JM samples (Fig. 3). Mussel spawning usually occurs as a synchronized phenomenon. Mass expulsion of gametes achieves optimal fertilization of eggs and probably promotes the survival of larvae during the pelagic phase (de Vooys 1999). Kautsky (1982b) observed ripening of mussel gonads in the Baltic Sea at 1 to $3{ }^{\circ} \mathrm{C}$ and strong relation of spawning to phytoplankton spring bloom. The areas with large mussel beds can produce larger quantities of spat, but it is known that the concentrations of pelagic larvae do not necessarily correlate with number of recruits (de Vooys 1999). In our study the experimental units JM-15, JM-20, JM-25 were located in a marine protected area with largest mussel and macroalgal beds in the region, accordingly yielding the largest larval biomass. On 20 May the abundance of larvae reached a peak and larvae of different size/age were observed in the zooplankton samples. The majority of planktonic larvae (70\%) in the middle of May reached $140 \mu \mathrm{m}$ size, which at this time could be 8 to 10 days old (Bayne 1965; Kautsky 1982b). The remaining of larvae (30\%) approached the size of the metamorphosis stage (200 to $240 \mu \mathrm{m}$ ); therefore we hypothesize that recruitment of mussels took place at the end of May-beginning of June.

\section{Influence of physiochemical variables on recruitment}

Mussels of the genera Mytilus can tolerate a wide range of environmental conditions and therefore they are one of few marine species adapted for living in the brackish Baltic Sea (Kautsky 1982a). Abiotic factors estimated on the Kurzeme coastline during the study period can be considered as suitable for mussel growing, as there are large natural mussel beds (Lagzdins et al. 1987). However, the Kurzeme coastline has a slanting depth profile allowing only two-dimensional colonization of available hard substrates. Installation of mussel farms would create the three-dimensional structure subjecting the mussels to under environmental gradients than would occur naturally.

The salinity, temperature, nutrient and food particle gradients due to the vicinity of the Curronian lagoon (Kozlov et al. 2014), may have influenced recruitment and growth of mussels on experimental units in our study. Strong influence of freshwater from the Curronian lagoon caused decrease of salinity during May in sites JM-15, JM20 and LI-15. Salinity changes were well above salinity limits considered as a threshold for Mytilus spp. tolerance (Kautsky 1982a); however they might have nevertheless been sufficient for slow growth of mussels, as the smallest mussels were found in JM-15.

Simultaneously, the lower salinity water was associated with significantly higher temperature (up to $14{ }^{\circ} \mathrm{C}$ in May), creating temporal stratification of water near coastal sites (JM-15, JM-20 and LI-15). This coincided with the largest numbers of mussel larvae (Fig. 3). It can hardly be hypothesized that increase of the temperature caused the massive spawning of mussels, as is described in literature (Riisgård et al. 1980), since the temporar stable stratification prevented the mixing of water mass and increase of temperature in the near bottom water layer. The spawning is better explained by inputs of warm water from the Curronian lagoon that contained large amounts of Dreissena polymorpha larvae. D. polymorpha colonizes the central part of the Curronian lagoon (Daunys et al. 2006; Zaiko et al. 2009). Its spawning begins at 12 to $15^{\circ} \mathrm{C}$, but its survival and recruitment is inhibited in the marine water (Orlova 2002). Accordingly, experimental units in the upper water layer ( 2 to $4 \mathrm{~m}$ ) containing the larger percentage of $D$. polymorpha larvae yielded lower amount of recruits in May at the JM site and probably the site was occupied by recruits of Mytilus from later (unsynchronized) spawning. However, the lower ropes (10 and $14 \mathrm{~m}$ ) submerged in different water mass were occupied by recruits of Mytilus, which explains the presence of significantly larger size mussels on the $10 \mathrm{~m}$ ropes at JM-15.

The best feeding conditions for mussels could be expected in JM-15 and JM-20, as the Curronian lagoon creates a gradient of nutrients and phytoplankton (Kozlov et al. 2014). However even temporal stratification restricts the water exchange between water layers, creating higher 
food availability in the upper water layer devoid of organisms able to profit, simultaneously decreasing the food availability for mussels below the thermocline. In contrast, sites PV-15, PV-20 and PV-25 suffered more from hydrodynamic forces (Sommere et al. 2011), but are evenly supplied with food, salinity, oxygen and temperature, and the best growth rate of Mytilus occurr at these sites.

\section{Conclusions}

The obtained results show that recruitment of mussels on artificial substrate is possible even near the high energy shores. Evidence showed that the number of planktonic larvae does not guaranty recruitment success, rather the harsh but uniform environmental conditions can promote the better survival and growth of recruits from less numerous spat. The maximum recruitment biomass was observed at 6 to $10 \mathrm{~m}$ depth, suggesting that submerged farming techniques should be used. If mussel farming is to take place on the Latvian coastline, locations with a well mixed water column outside of freshwater influence should be looked for.

\section{Acknowledgements}

This research was performed during the project: "Commercial mussel farming, processing and end-use in the Baltic Sea Region" (Baltic EcoMussel) (Central Baltic Interreg IV A programme) under subcontract of the Latvian Environmental Investment Fund (No. ATT2013-1) and Kurzeme Planning Region (No. 8-5/ CB58/3). We would like to thank Zaiga Ozolina at the Latvian Environmental Investment Fund and Ligita Laipiniece at the Kurzeme Planning Region for their cooperation. The preparation of themanuscript was supported by the project "Initiating full scale mussel farming in the Baltic Sea" (Baltic Blue Growth) (Interreg Baltic Sea Region programme) (No. R031).

\section{References}

Asmus R.M., Asmus H. 1991. Mussel beds: limiting or promoting phytoplankton? J. Exp. Mar. Biol. Ecol. 148: 215-232.

Bayne B.L. 1965. Growth and the delay of metamorphosis of the larvae of Mytilus edulis (L.). Ophelia 2: 1-47.

Dame R., Dankers N. 1988. Uptake and release of materials by a Wadden Sea mussel bed. J. Exp. Mar. Biol. Ecol. 118: 207-216.

Dankers N., Zuidema D.R. 1995. The role of the mussel (Mytilus edulis L.) and mussel culture in the Dutch Wadden Sea. Estuaries 18: 71-80.

Daunys D., Zemlys P., Olenin S., Zaiko A., Ferrarin C. 2006. Impact of the zebra mussel Dreissena polymorpha invasion of the budget of suspended material in a shallow lagoon ecosystem. Helgol. Mar. Res. 60: 113-120.

de Vooys C.G.N. 1999. Numbers of larvae and primary plantigrades of the mussel Mytilus edulis in the western Dutch Wadden Sea. J. Sea Res. 41: 189-2001.

Dittmann S. 1990. Mussel beds: amensalism or amelioration for intertidal fauna? Helgol Meeresunt 44: 335-352.
Gosling E. (ed) 2003. Bivalve Molluscs: Biology, Ecology and Culture. Blackwell Publishing, 443 p.

Kautsky N. 1982a. Growth and size structure in a Baltic Mytilus edulis population. Mar. Biol. 68: 117-133.

Kautsky N. 1982b. Quantitative studies on gonad cycle, fecundity, reproduction output and recruitment in the Baltic Mytilus edulis population. Mar. Biol. 68: 143-160.

Kostrichkina E.M., Kaleja M.A 1980. Distribution, seasonal and perennial dynamics of zoobenthos in the Baltic Sea. In: Rybokhozyaistvennye issledovaniya $v$ basseine Baltiyskogo morya. Avots, Riga, pp. 118-128. /in Russian/

Kozlov I., Dailidiené I., Korosov A., Klemas V., Mingélaité T. 2014. MODIS-based sea surface temperature of the Baltic Sea Curonian Lagoon. J. Mar. Syst. 129: 157-165

Krūmiņš R., Ozoliṇa I. 1998. General lithological and geomorphological map of Latvian shore zone - Baltic sea and Gulf of Riga. State Geological Survey of Latvia, Riga.

Lagzdins G.S., Saule A.H., Pallo P.E. 1987. Coastal zoobenthos in the Eastern Baltic Proper, the Gulf of Riga and the Gulf of Finland. In: Hydrobiological and hydrochemical characteristics of the eastern part of Baltic Sea. The Gulf of Riga and the Gulf of Finland. Riga, Zinatne, pp. 164-180. /in Russian/

Lindahl O., Hart R., Hernroth B., Kollberg S., Loo L.O., Olrog L., Rehnstam-Holm A.S., Svensson J., Svensson U., Syversen U. 2005. Improving marine water quality by mussel farming: a profitable solution for Swedish society. Ambio 34: 131-138.

Müller-Karulis B., Jermakovs V., Aigars J. 2007. The modelling of Furcellaria lumbricalis habitats along the Latvian coast. BALANCE Project Report No. 23, 1-25.

Olenin S. 1997. Benthic zonation of the Eastern Gotland Basin, Baltic Sea. Neth. J. Aquat. Ecol. 30: 265-282.

Orlova M.I. 2002. Dreissena biology and invasion success. In: Leppäkoski E., Gollasch S., Olenin S. (eds) Invasive Aquatic Species of Europe - Distribution, Impact and Management. Dordrecht, Boston, London. Kluwer Academic Publishers, pp. 127-134.

Riisgård H.U., Randløv A., Kristensen P.S. 1980. Rates of waterprocessing, oxygen consumption and efficiency of particle retention in veliger and young post-metamorphic Mytilus edulis. Ophelia 19: 37-47.

Saier B. 2002. Subtidal and intertidal mussel beds (Mytilus edulis L.) in the Wadden Sea: diversity differences of associated epifauna. Helgol. Mar. Res. 56: 44-50.

Seed R. 1969. The ecology of Mytilus edulis L. (Lamellibranchiata) on exposed rocks shores. II. Growth and mortality. Oecologia 3: 317-350.

Soomere T., Viška M., Lapinskis J., Räämeta A. 2011. Linking wave loads with the intensity of erosion along the coasts of Latvia. Estonian J. Eng. 17: 359-374.

Sunila I. 1981. Reproduction of Mytilus edulis L. (Bivalvia) in a brackish water area, the Gulf of Finland. Ann. Zool. Fennici 18: 121-128.

Verwey J. 1952. On the ecology of distribution of cockle and mussels in the Dutch Waddensea, their role in sedimentation and the source of their food supply. Arch. Néerl. Zool. 10: 171239.

Zaiko A., Daunys D., Olenin S. 2009. Habitat engineering by the invasive zebra mussel Dreissena polymorpha (Pallas) in a boreal coastal lagoon: impact on biodiversity. Helgol. Mar. Res. 63: 85-94. 